\title{
Identification of stem rust resistance genes in wheat cultivars in China using molecular markers
}

\author{
Xiaofeng Xu ${ }^{1}$, Depeng Yuan ${ }^{1}$, Dandan $\mathrm{Li}^{1}{ }^{1}$, Yue Gao ${ }^{1}$, Ziyuan Wang ${ }^{1}$, Yang Liu ${ }^{1}$, Siting Wang ${ }^{1}$, Yuanhu \\ Xuan ${ }^{1}$, Hui Zhao ${ }^{2}$, Tianya $\mathbf{L i}^{\text {Corresp., }}{ }^{1}$, Yuanhua Wu ${ }^{1}$ \\ ${ }^{1}$ College of Plant Protection, Shenyang Agricultural University, Shenyang, China \\ 2 Henan Academy of Agricultural Science, Institute of Plant Protection, Henan, China \\ Corresponding Author: Tianya Li \\ Email address: Litianya11@syau.edu.cn
}

Wheat stem rust caused by Puccinia graminis f. sp. tritici Eriks. \& E. Henn. (Pgt), is a major disease that has been effectively controlled using resistance genes. The appearance and spread of Pgt races such as Ug99, TKTTF, and TITTF, which are virulent to most stem rust resistant genes currently deployed in wheat breeding programs, renewed the interest in breeding cultivars resistant to wheat stem rust. It is therefore important to investigate the levels of resistance or vulnerability of wheat cultivars to Pgt races. Resistance to Pgt races 21C3CTHQM, 34MKGQM, and 34C3RTGQM was evaluated in 136 Chinese wheat cultivars at the seedling stage. One hundred and twenty four of these cultivars (91.2\%) were resistant to the three races. Resistance genes Sr2, Sr24, Sr25, Sr26, Sr31, and Sr38 were analyzed using molecular markers closely linked to them, and 63 of the 136 wheat cultivars carried at least one of these genes: 21,25 , and 28 wheat cultivars likely carried Sr2, Sr31, and Sr38, respectively. Cultivars 'Kehan 3' and 'Jimai 22' likely carried Sr25. None of the cultivars carried Sr24 or Sr26. These cultivars with known stem rust resistance genes provide valuable genetic material for breeding resistant wheat cultivars. 
1 Identification of stem rust resistance genes in wheat cultivars in China using molecular

2 markers

3 Xiaofeng Xu ${ }^{\# 1}$, Depeng Yuan ${ }^{\# 1}$, Dandan $\mathrm{Li}^{1}$, Yue Gao ${ }^{1}$, Ziyuan Wang ${ }^{1}$, Yang Liu ${ }^{1}$, Siting

4 Wang ${ }^{1}$, Yuanhu Xuan ${ }^{1}$, Hui Zhao ${ }^{2}$, Tianya Li $^{* 1}$, Yuanhua Wu*1

$5{ }^{1}$ College of Plant Protection, Shenyang Agricultural University, Shenyang, Liaoning, 110866

6 China

7 Institute of Plant Protection, Henan Academy of Agricultural Science, Zhengzhou, Henan, 8450002 China

9 \#These authors contributed equally to this work.

$10 *$ Corresponding authors

11 Phone/Fax: +86 248834 2056, litianya11@syau.edu.cn (Tian Ya Li) or

12 Phone/Fax: +86 248834 2056,wuyh7799@163.com(Yuanhua Wu)

\section{Abstract}

14 Wheat stem rust caused by Puccinia graminis f. sp. tritici Eriks. \& E. Henn. (Pgt), is a major

15 disease that has been effectively controlled using resistance genes. The appearance and spread of

16 Pgt races such as Ug99, TKTTF, and TTTTF, which are virulent to most stem rust resistant

17 genes currently deployed in wheat breeding programs, renewed the interest in breeding cultivars

18 resistant to wheat stem rust. It is therefore important to investigate the levels of resistance or

19 vulnerability of wheat cultivars to Pgt races. Resistance to Pgt races 21C3CTHQM, 34MKGQM,

20 and 34C3RTGQM was evaluated in 136 Chinese wheat cultivars at the seedling stage. One

21 hundred and twenty four of these cultivars (91.2\%) were resistant to the three races. Resistance 
22 genes $\operatorname{Sr} 2, \operatorname{Sr} 24, \operatorname{Sr} 25, \operatorname{Sr} 26, \operatorname{Sr} 31$, and $\operatorname{Sr} 38$ were analyzed using molecular markers closely

23 linked to them, and 63 of the 136 wheat cultivars carried at least one of these genes: 21,25 , and

2428 wheat cultivars likely carried $S r 2, S r 31$, and $S r 38$, respectively. Cultivars 'Kehan 3' and

25 'Jimai 22' likely carried Sr25. None of the cultivars carried Sr24 or Sr26. These cultivars with

26 known stem rust resistance genes provide valuable genetic material for breeding resistant wheat

27 cultivars.

\section{Introduction}

Wheat stem rust caused by Puccinia graminis Per. f. sp. tritici Eriks. \& E. Henn. (Pgt) is a devastating disease that has caused severe yield losses worldwide. Since the deployment of stem rust-resistant wheat cultivars in the second half of the 20th century, stem rust has been successfully controlled in most wheat cultivating areas (Chen et al., 2015). However, a new race of the stem rust pathogen (Ug99), identified in Uganda in 1999 and highly virulent to resistance gene Sr31, was designated as TTKSK under the North American nomenclature system (Pretorius et al., 2000). Within a few years, virulence of TTKSK to other important stem rust resistance genes (e.g., $S r 24, S r 36, S r 9 h, S r 31+S r 24, S r 31+S r 36$, and $S r 31+S r T m p)$ was detected (BGRI 2017; Jin et al., 2008; Jin et al., 2009; Pretorius et al., 2012; Rouse et al., 2014), and 13 variants of Ug99 have now been documented across wheat growing regions in 13 countries (FAO 2017). Realizing the disastrous threat on world food security posed by the Ug99 race group, Nobel Peace Prize laureate Norman Borlaug called for a coordinated global campaign to reduce wheat rust epidemics and mitigate the potential impact on food security. The resistance of worldwide wheat accessions (over 200, 000) to the Ug99 group was screened in Kenya (He et al., 2008). 
43 The results indicated that only $5-15 \%$ of the wheat accessions grown globally were resistant to

44 Ug99, and only two of the 118 Chinese wheat cultivars ('Jimai 20' and 'Linmai 6') were

45 resistant to Ug99. The high susceptibility (85-95\%) of wheat lines to Ug99 highlighted the

46 potential threat of this group to wheat production worldwide. Furthermore, other broadly virulent

47 Pgt races caused wheat stem rust epidemics in recent years. The new race TKTTF (from a

48 genetic lineage distinct from that of Ug99) virulent to the widely grown wheat cultivar 'Digalu',

49 caused yield losses close to 100\% in Southern Ethiopia during 2013-2014 (Olivera et al., 2015).

50 In 2016, a new and unusually devastating strain of $P g t$ named TTTTF (virulent to $S r 9 e$ and $S r 13$ )

51 caused the largest outbreak and epidemics of wheat stem rust in Sicily since the 1950s

52 (Bhattacharya 2017), as tens of thousands of hectares of both durum wheat and bread wheat were

53 infected. Thus, wheat stem rust seems to have returned.

54 The most effective way to control wheat stem rust is by using resistant genes against this

55 disease to breed and propagate resistant varieties (Pathan et al., 2007). However, an important

56 issue in the use of resistant varieties is that the simplification of the resistance source may be

57 overcome by variation in the pathogen, resulting in the loss of resistance. Understanding

58 resistance gene content of wheat varieties can effectively avoid this situation, and provide a basis

59 for the reasonable distribution of varieties. Moreover, it is also helpful to discover new genes,

60 enriching the gene pool, and for breeding resistant varieties. Nevertheless, the spread of new Pgt

61 races and their variants threatens the safety of wheat production in China (Li et al., 2016). If the

62 conditions are suitable, there is the possibility of wheat stem rust becoming a significant disease.

63 Because the resistance of Chinese wheat varieties to the new races Ug99, TKTTF, and TTTTF is 
64

very poor, if these races spread into China they will cause massive losses in wheat production (Cao et al., 2007). We should therefore make full use of wheat cultivar resources to screen for resistant materials. Given the importance of understanding disease resistance genes, those against Ug99, TKTTF, and TTTTF races have been screened and identified worldwide since these races were reported.

In our previous study, the prevalence of $\operatorname{Sr} 2, \operatorname{Sr} 24, \operatorname{Sr} 25, \operatorname{Sr} 26, \operatorname{Sr} 31$, and $\operatorname{Sr} 38$ in wheat cultivars from Gansu and Yunnan Province has been finished (Li et al., 2016; Xu et al., 2017), and based on it, this study was carried out. We collected 136 wheat cultivars from two different localities presenting epidemic patterns of wheat stem rust to examine their resistance level to the predominant races of $\mathrm{Pgt}$ in China. Resistance genes $\mathrm{Sr} 2, \mathrm{Sr} 24, \mathrm{Sr} 25, \mathrm{Sr} 26, \mathrm{Sr} 31$, and $\mathrm{Sr} 38$ were detected using molecular markers aiming to screen and identify cultivars that are potentially resistant to emerging races (especially to Ug99, TKTTF, and TTTTF) and map the distribution of those genes in wheat regions based on wheat cultivars' resistance level to predominant races of Pgt. Thus far, our team have identified and characterized these resistant genes in four wheatproducing regions of China (Fig. 1), which will contribute to the deployment of wheat stem rust resistance genes and control of large-scale epidemics of this disease. Additionally, this information will be important for developing potentially durable combinations of stem rust resistance genes in wheat cultivars.

\section{Materials and Methods}

\section{Wheat cultivars (lines) and Pgt races}

One hundred and thirty six wheat cultivars (lines) were collected from the largest wheat 
85

86

87

growing regions in China: the Northeastern spring-wheat growing provinces and the lowermiddle Yangtze River basin and central winter-wheat growing provinces. All wheat accessions were provided by researchers from Heilongjiang, Inner Mongolia, Shandong, Shanxi, Anhui, Jiangsu, Beijing, and Ningxia Academies of Agricultural Sciences. Six monogenic wheat lines carrying individual $\mathrm{Sr}$ genes $(\mathrm{Sr} 2, \mathrm{Sr} 24, \mathrm{Sr} 25, \mathrm{Sr} 26, \mathrm{Sr} 31$, and $\mathrm{Sr} 38)$, and 29 differentials for $P g t$, including the original four Stakman differentials (Little Club (LC), Reliance, Einkorn, and Vernal), five Chinese differentials (Mianzi 52, Huadong 6, Mini 2761, Orofen, and Rulofen), and 20 single $S r$-gene lines from North America (Sr5, Sr21, Sr9e, $\operatorname{Sr} 7 b, \operatorname{Sr} 11, \operatorname{Sr} 6, \operatorname{Sr} 8 a, \operatorname{Sr} 9 g, \operatorname{Sr} 36$, $\operatorname{Sr} 9 b$, $\operatorname{Sr} 30, \operatorname{Sr} 17, \operatorname{Sr} 9 a, \operatorname{Sr} 9 d, \operatorname{Sr} 10, \operatorname{SrTmp}, \operatorname{Sr} 24, \operatorname{Sr} 31, \operatorname{Sr} 38$, and $\operatorname{SrMcN}$ ) used worldwide, were provided by the Plant Immunity Institute, Shenyang Agricultural University, China.

Races 21C3CTHQM (Pgt isolate Ab3), 34MKGQM (Pgt isolate H31), and 34C3RTGQM (Pgt isolate XN11) (a new race identified from the alternative host Berberis sp.) were used for evaluating seedling stem rust response in the tested cultivars. These races were isolated and identified by the Plant Immunity Institute, Shenyang Agricultural University, China. The names, virulence/avirulence spectrums, and urediniospores produced method of races were described by Li et al., (2016) and Xu et al. (2017).

\section{Seedling infection types}

The 136 wheat accessions were planted in 10-cm diameter porcelain pots (each pot contained one cultivar represented by eight to 10 seedlings). A mixture of urediniospores and dried talc (1 g), in a ratio of 1:20 (v:v), was sprayed onto the fully expanded primary leaves of seedling (seven to eight days old) moistened with $0.05 \%$ Tween-20. The detail inoculation and cultivation 
106

107

108

109

110

111

112

113

114

115

116

117

118

119

120

121

122

123

124

125

126

methods followed $\mathrm{Xu}$ et al. (2017). Three replicates of the seedling assays were performed for each $P g t$ race. Infection types were assessed two weeks after inoculation using the $0-4$ Infection

Type (IT) scale, as described by Stakman et al. (1962).

\section{DNA extraction}

DNA was extracted from the young leaves of seven-day old seedlings grown to the one-leaf stage, using a DNA extraction kit (Sangon Biotech, Shanghai, China). PCR amplifications were followed Xu et al. (2017). Primers were synthesized by Sangon Biotech (China) (Table 1), and PCR amplification conditions were as described in previous studies (Table 1). Fragments of the targeted genes were detected by electrophoresis using $2 \%(\mathrm{~W} / \mathrm{V})$ agarose gels and then gels were observed under UV light.

\section{Results}

\section{Wheat seedling resistance}

The ITs produced by wheat cultivars to races 21C3CTHQM, 34MKGQM, and 34C3RTGQM are listed in Table 2. One hundred and twenty four (91.2\%) wheat cultivars were resistant to the three races (ITs $2,1+$, or lower) while the remaining 12 were susceptible (ITs 3-, 3, 3+, and 4) (Fig. 2). Forty-eight wheat cultivars (35.3\%) showed IT 0 to all tested races (Fig. 2) and 127 showed resistance to the new race 34C3RTGQM.

\section{Detection of stem rust resistance genes using molecular markers}

\section{Sr2 screening}

The adult plant resistant gene $S r 2$, which provides a durable broad-spectrum to Pgt is difficult to screen under field conditions (Hayden et al., 2004). However, the Sr2-closely linked 
127 microsatellite marker Xgwm533, developed by Hayden et al. (2004), typically amplifies a 120-bp

128 fragment from wheat lines known to carry Sr2. In the present study, we used this marker to

129 detect $\operatorname{Sr} 2$ and 21 of the 136 wheat varieties showed the $\operatorname{Sr} 2$ fragment (Fig. 1A, Table 2),

130 suggesting that those wheat varieties carry $\operatorname{Sr} 2$.

\section{$131 \quad$ Sr24 screening}

132 Gene $S r 24$ is effective against some Pgt races in China and it was derived from T. ponticum. It is

133 widely used in wheat breeding though it has become susceptible to some Ug99 variants (Jin et al.,

134 2008). Mago et al. (2005) reported that marker $S r 24 \# 12$, linked to $S r 24$, was associated with the

$1353 \mathrm{Ag} / \mathrm{BS}$ Amigo-type translocation, and this marker can amplify a 500-bp fragment in the wheat

136 variety 'Westonia/Sr24'. Using a diverse collection of wheat germplasm, Yu et al. (2010)

137 showed that this 500-bp PCR fragment was amplified in wheat germplasm carrying $\operatorname{Sr} 24$. In the

138 present study, 500-bp fragments were amplified in the wheat line 'LcSr24Ag', suggesting it

139 carries $\operatorname{Sr} 24$ (Fig. 3B) but no fragment was amplified in the other tested varieties (Table 2).

\section{$140 \quad S r 25$ and $S r 26$ screening}

141 Ug99-effective-genes Sr25 and Sr26 were transferred into wheat from Thinopyrum ponticum.

142 These two genes were firstly backcrossed into Australian wheat, and some old varieties may

143 carry these genes in China (Cao et al., 1994; Knott 1961). We used markers Gb (amplifies a 130-

144 bp fragment) and $S r 26 \# 43$ (amplifies a 207-bp fragment), which are closely linked to genes $S r 25$

145 and $\operatorname{Sr} 26$, respectively (Liu et al., 2010), to screen these genes in the 136 accessions. The 130-bp

146 fragment was only amplified in Kehan 3 and Jimai 22 (Fig. 3C and Table 2), indicating that only

147 these two wheat varieties carry Sr25; the other tested wheat varieties lack Sr25 and Sr26 (Fig. 3D 
148 and Table 2).

\section{$149 \quad S r 31$ and $S r 38$ screening}

150 The effective resistance of $\operatorname{Sr} 31$ and $\operatorname{Sr} 38$ to Pgt was overcome by Ug99, as no race with

151 virulence to these genes had been found in China (Li et al., 2016). Genes $\operatorname{Sr} 31$ and $\operatorname{Sr} 38$ were 152 widely used in wheat programs. Markers SCSS30.2 576 (amplifies a 576-bp fragment) and Iag95 153 (amplifies a 1100-bp fragment) linked to Sr31, and the 2NS-specific primer VENTRIUP-LN2 154 (amplifies a 262-bp fragment), linked to the rust resistance gene cluster $\operatorname{Lr} 37-\operatorname{Sr} 38$ - $\operatorname{Yr} 17$, were 155 used in the present study to screen Sr31 and Sr38. Fragment sizes consistent with the presence of 156 both resistant genes were amplified in 25 wheat cultivars and in the positive control 157 Sr31/6*LMPG using markers SCSS30.2576 and Iag95, and in 28 wheat cultivars using marker

158

159

160

161

162

163

164

165

166

167

168

VENTRIUP-LN2.

\section{Discussion}

It is reported that the resistance of wheat cultivars to Pgt is higher in the northern rather than in the southern wheat region, especially in varieties from North China where stem rust is prone to occur. Results obtained in the present study are similar to that previously reported. In total, 124 $(91.2 \%)$ wheat cultivars were resistant to the three Pgt races (ITs 2, 1+, or lower), and the resistance level of the accessions from Heilongjiang was higher than that of accessions from other provinces. All wheat cultivars from Heilongjiang Province were resistant to races 21C3CTHQM, 34MKGQM, and 34C3RTGQM, as wheat lines must be resistant to Pgt for being registered in Heilongjiang. In addition, the resistance level of wheat lines from Heilongjiang is tested by the Plant Immunity Institute, Shenyang Agricultural University, every year using the 
$16921 \mathrm{C} 3$ and $34 \mathrm{Pgt}$ race groups. Therefore, all registered cultivars registered in Heilongjiang

170 should present ITs below 3, which was confirmed in the present study $(0,1,1-$, and 2 ITs were

171 found; Table 2). Wheat cultivars from the lower-middle Yangtze River basin and central winter-

172 wheat growing provinces were also highly resistant $(73.9 \%)$ to the tested $P g t$ races.

173 Gene Sr2, originated from Triticum dicoccum Schronk, was transferred into North American

174 and International Maize and Wheat Improvement Center (CIMMYT) wheat breeding programs

175 in 1925, and since then it has been extensively used in many regions worldwide (Borlaug 1968).

176 In the present study, marker $X g w m 533$, which was used to detect $\operatorname{Sr} 2$, revealed that only 21 of

177 the 136 wheat varieties were likely to carry this gene. Such cultivars might be resistant to Ug99,

178 as the high resistance of Jimai 20 to Ug99 tested in Kenya in 2006 has been attributed to the $S r 2$

179 gene carried by this cultivar (He, Xia\&Chen, 2008). But it is difficult to conclude that these 21

wheat varieties carry $S r 2$, because many North American, Australian and CIMMYT lines which

predicted not carry this gene can amplified a 120-bp fragment (Jemanesh et al., 2013; Mago et al.,

2011).

The wheat stem rust gene $S r 24$, derived from $T$. ponticum, is effective against most Pgt races,

including race TTKSK (i.e., Ug99). Races virulent to $\mathrm{Sr} 24$ are rare in Pgt population in North

America (Jin et al., 2008). This gene has been used as a differential in North America and

worldwide race surveys, but a new variant of race TTKSK with $S r 24$ virulence has arisen in

Kenya, South Africa, Tanzania, Ethiopia, Mozambique, and Uganda (BGRI 2017). Leaf rust

gene $\mathrm{Lr} 24$ in association with $\mathrm{Sr} 24$ provides resistance to all Pgt isolates. Thus, we used marker

$\operatorname{Sr} 24 \# 12$, completely linked to $\operatorname{Sr} 24$ (Mago et al., 2005), to screen for $S r 24 / L r 24$ genes in the 136 
190

191

192

193

194

195

196

197

198

199

200

201

202

203

204

205

206

207

208

209

210

wheat accessions. None of the tested cultivars carried Sr24, although previous research using gene postulate showed that some Chinese wheat cultivars carried this gene (Cao et al., 2007). On the other hand, the study conducted by Zhang et al. (Zhang et al., 2008) supports our result as none of the 23 wheat cultivars they screened using molecular markers linked to $\operatorname{Lr} 24$ carried this gene. Thus, more races and molecular markers should be used to confirm whether Chinese wheat cultivars carry $\mathrm{Sr} 24$ or not.

Genes $S r 25$ and $S r 26$, derived from $T$. ponticum, are effective against Ug99 and all Pgt races in China, and their use is increasing based on their resistance to Ug99 (Bariana et al., 2007). Novel genetic tools based on molecular marker technologies were developed to tag the presence of those genes (Mago et al., 2005; Liu et al., 2010). In the present study, we used molecular markers $G b$, linked with $S r 25$, and $S r 26 \# 43$, linked with $\operatorname{Sr} 26$, to identify these genes. Two wheat cultivars, 'Kehan 3'(Ke61F ${ }_{3}$-199/Agropyronglaucum) and 'Jimai 22' (935024/935106) are likely to carry Sr25. Pedigree tracking indicated that 'Kehan 3' parents contained A. glaucum, but $\operatorname{Sr} 25$ is derived from T. ponticum, so the result obtained for this cultivar might not be accurate. Expectedly, none of the wheat varieties carried $S r 26$, as this gene is not widely used in breeding programs in China ( $\mathrm{Li}$ et al., 2016). Results obtained here are similar to those of previous studies; for example, using marker Sr26\#43, Li et al. (Li et al., 2016) detected that none of the 119 wheat materials examined carried $\operatorname{Sr} 26$.

Gene $\mathrm{Sr} 31$, derived from 'Petkus' rye, is located on $1 \mathrm{BL} / 1 \mathrm{RS}$. It is distributed in wheat cultivars worldwide, but was transferred into Chinese wheat backgrounds from the Soviet Union and Romania in the 1960s (Jiang et al., 2007). Since then, the wheat cultivars 'Alondra S', 
211 'Aftab LeEr', 'Kavkaz', and 'Luofulin' lines carrying Sr31 have been released in wheat growing

212 regions in China. Although, this gene is susceptible to Ug99, it is effective against TKTTF and

213 TTTTF and all Pgt races in China (Pretorius et al., 2000; Olivera et al., 2015; Bhattacharya 2017;

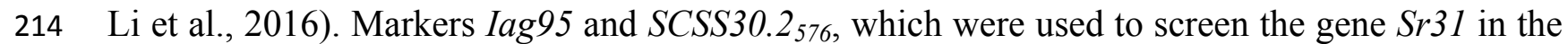
215 present study, revealed that 25 wheat cultivars contained Sr31, and pedigree information and low 216 ITs supported these results. Thus, Sr31 should be used in breeding programs in China in 217 combination with other genes resistant to Ug99 to ensure that Chinese wheat cultivars are 218 resistant to Chinese Pgt races and to Ug99.

219 Gene $\operatorname{Sr} 38$, originated from $T$. ventricosum, is widely used due to its association with the stripe rust gene $\operatorname{Yr} 17$ and the leaf rust gene $\operatorname{Lr} 37$ that confer resistance to the three species of wheat rust pathogens (Delibes et al., 1993; Dyck\&Lukow 1988). Genes $\operatorname{Yr} 17$ and Lr37 were reported from wheat cultivars in China using molecular markers linked to them (Peng et al., 2013; Xue et al., 2014). In the present study, the marker VENTRIUP-LN2, which is linked with the Sr38-Yr17Lr37 cluster of rust resistance genes, was used and the specific PCR fragment for this marker was detected in 28 of the 136 wheat cultivars examined. These 28 cultivars presented low ITs indicating they carry $\mathrm{Sr} 38$. Gene $\mathrm{Sr} 38$ is susceptible to $\mathrm{Ug} 99$, similar to gene $\mathrm{Sr} 31$, but resistant to all Pgt races in China (Cao et al., 2007). Therefore, in China, it should be used in combination with genes resistant to Ug99 through gene pyramiding.

229 Molecular markers linked to resistance genes are an alternative to gene postulation and may 230 allow breeders to identify resistance genes rapidly and accurately (Goutam et al., 2013). 231 Combining molecular markers with pedigree information of the tested varieties can greatly 
232 increase the success of gene postulation ( $\mathrm{Yu}$ et al., 2010). Due to the rapid development of

233 molecular markers and to the great importance of the new Pgt races, molecular markers closely

234 linked to resistance genes against such races have been frequently reported, and many have been

235 converted to simple sequence repeat (Mago et al., 2013; Tsilo, Jin \& Anderson 2007), sequence

236 tagged site/cleaved amplified polymorphic sequence (Helguera et al., 2003; Mago et al., 2011),

237 sequence tagged site (Mago et al., 2005; Bansal et al., 2014), and simple sequence

238 repeats/amplified fragment length polymorphism markers (Periyannan et al., 2014). This

239 approach overcomes gene interactions and plant stage-dependent gene expression problems

240 associated with traditional gene postulation.

\section{Conclusion}

242 In the present study, we used molecular markers to determine if $\operatorname{Sr} 2, \operatorname{Sr} 24, \operatorname{Sr} 25, \operatorname{Sr} 26, \operatorname{Sr} 31$, 243 and $\operatorname{Sr} 38$ were present in the 136 wheat cultivars examined. Overall, genes $\operatorname{Sr} 31$, and $\operatorname{Sr} 38$ were 244 differently distributed across wheat regions in China and none of the wheat cultivars contained $245 \operatorname{Sr} 24$ and $\operatorname{Sr} 26$. Additional studies will be needed to verify the gene postulations for $\operatorname{Sr} 2$ and $\operatorname{Sr} 25$.

246 These cultivars comprising stem rust resistance genes are valuable genetic materials for future 247 wheat-breeding plans.

\section{Acknowledgments}

249 We appreciate very much Dr. Qingjie Song, Dr. Hongji Zhang, and Dr. Yantai Guo at Heilongjiang Academy of Agricultural Science; Dr. Jiandong Han at Shandong Academy of 
253 providing the wheat cultivars.

\section{References}

255 Chen SS, Rouse MN, Zhang WJ, Jin·Y, Akhunov E, Wei YM, and Dubcovsky J. 2015. Fine

256 mapping and characterization of $\operatorname{Sr} 21$, a temperature-sensitive diploid wheat resistance gene

257 effective against the Puccinia graminis f. sp. tritici Ug99 race group. Theoretical and Applied

$258 \quad$ Genetics 128: 645-656.

259 Pretorius ZA, Singh RP, Wagoire WW, and Payne TS. 2000. Detection of virulence to wheat

260 stem rust resistance gene Sr31 in Puccinia graminis f. sp. tritici in Uganda. Plant Disease 84:

261203.

262 BGRI. A Global Wheat Rust Monitoring System. 2017. Available from:

263 http://rusttracker.cimmyt.org/?page_id=22

264 Jin Y, Szabo LJ, Pretorius ZA, Singh RP, Ward R, and Fetch TJr. 2008. Detection of virulence to

265 resistance gene $S r 24$ within race TTKS of Puccinia graminis f. sp. tritici. Plant Disease 92:

$266923-926$.

267 Jin Y, Szabo LJ, Rouse MN, Fetch TJr, Pretorius ZA, Wanyera R, and Njau P. 2009. Detection

268 of virulence to resistance gene Sr36 within the TTKS race lineage of Puccinia graminis f. sp

269 tritici. Plant Disease 93: 367-370.

270 Pretorius ZA, Szabo G, Boshoff WHP, Herselman L, and Visser B. 2012. First report of a new

271 TTKSF race of wheat stem rust (Puccinia graminis f. sp. tritici) in South Africa and 272 Zimbabwe. Plant Disease 96: 590.

273 Rouse MN, Nirmala J, Jin Y, Chao SM, Fetch TJr, Pretorius ZA, and Hiebert CW. 2014. 
274 Characterization of $\mathrm{Sr} 9 \mathrm{~h}$, a wheat stem rust resistance allele effective to Ug99. Theoretical and Applied Genetics 127: 1681-1688.

276 FAO. Spread of damaging wheat rust continues: new races found in Europe, Africa, Central Asia. 2017. 3 February. Available at http://www.fao.org/news/story/en/ item/46946 7/icode/

He ZH, Xia XC, and Chen WQ. 2008. Breeding for resistance to new race Ug99 of stem rust pathogen. Journal of Triticeae Crops 28: 170-173.

Olivera P, Newcomb M, Szabo LJ, Rouse M, Johnson J, Gale S, Luster DG, Hodson D, Cox JA, Burgin L, Hort M, Gilligan CA, Patpour M, Justesen AF, Hovmøller MS, Woldeab G, Hailu E, Hundie B, Tadesse K, Pumphrey M, Singh RP, and Jin Y. 2015. Phenotypic and genotypic

Xu XF, Li DD, Liu Y, Gao Y, Wang ZY, Ma YC, Yang S, Cao YY, Xuan YH, and Li TY. 2017. Sr38 in wheat lines from Gansu Province in China. Peer J 5: e4146. characterization of race TKTTF of Puccinia graminis f. sp. tritici that caused a wheat stem rust Epidemic in Southern Ethiopia in 2013-14. Phytopathology 105: 917-928.

Bhattacharya S. 2017. Deadly new wheat disease threatens Europe's crops. Nature 542: 145-146.

Pathan AK, and Park RF. 2007. Evaluation of seedling and adult plant resistance to stem rust in European wheat cultivars. Euphytica 155: 87-105.

Li TY, Cao YY, Wu XX, Xu XF, and Wang WL. 2016. Seedling resistance to stem rust and molecular marker analysis of resistance genes in wheat cultivars of Yunnan, China. Plos One 11:e0165640.

Evaluation and identification of stem rust resistance genes $\operatorname{Sr} 2, \operatorname{Sr} 24, \operatorname{Sr} 25, \operatorname{Sr} 26, \operatorname{Sr} 31$ and

94 Cao YY, Han JD, Zhu GQ, and Zhang L. 2007. Ug99, a new virulent race of Puccinia graminis f. 
sp. tritici, and its effect on China. Plant Protection 6: 86-89.

296

297

298

299

300

301

302

303

304

305

306

307

308

309

310

311

312

313

314

315

Stakman EC, Stewart DM, and Loegering WQ. 1962. Identification of physiologic races of Puccinia graminis var. tritici. US Department of Agric ARSE-617, p53.

Hayden MJ, Kuchel H, and Chalmers KJ. 2004. Sequence tagged microsatellites for the Xgwm533 locus provide new diagnostic markers to select for the presence of stem rust resistance gene Sr2 in bread wheat (Triticum aestivum L.). Theoretical and Applied Genetics 109: $1641-1647$.

Mago R, Bariana HS, Dundas IS, Spielmeyer W, and Lawrence GL. 2005. Development of PCR markers for the selection of wheat stem rust resistance genes $\mathrm{Sr} 24$ and $\mathrm{Sr} 26$ in diverse wheat germplasm. Theoretical and Applied Genetics 111: 496-504.

Yu L, Liu S, Anderson JA, Singh RP, Jin Y, Dubcovsky J, Gina BJ, Bhavani S, Morgounov A, He Z, Huerta-Espino J, and Sorrells ME. 2010. Haplotype diversity of stem rust resistance loci in uncharacterized wheat lines. Molecular Breeding 26: 667-680.

Cao YY, Yao P, Zhu GQ, and Wu YS. 1994. A preliminary analysis of probable genes for stem rust resistance and resistance stability of 41 wheat cultivars in China. Journal of Shenyang Agricultural University 25: 392-397.

Knott DR. 1961. The inheritance of rust resistance VI. The transfer of stem rust resistance from Agropyron elongatum to common wheat. Canadian Journal of Plant Science 41: 109-123.

Liu S, Yu LX, Singh RP, Jin Y, Sorrells ME, and Anderson JA. 2010. Diagnostic and codominant PCR markers for wheat stem rust resistance genes Sr25 and Sr26. Theoretical and Applied Genetics 120: 691-697. 
316 Borlaug NE. 1968. Wheat breeding and its impact on world food supply. In: Finlay KW,

317 Shephard KW (eds) Proceedings of the 3rd International Wheat Genetics Symposium. 318 Australian Academy of Sciences, Canberra, pp 1-36.

319 Haile JK, Hammer K, Badebo A, Singh RP, and Roder S. 2013. Haplotype analysis of molecular 320 markers linked to stem rust resistance genes in Ethiopian improved durum wheat varieties and tetraploid wheat landraces. Genet Resour Crop Evol, 60: 853-864.

Mago R, Brown-Guedira G, Dreisigacker S, Breen J, Jin Y, Singh R, Appels R, Lagudah ES, Ellis J, and Spielmeyer W. 2011. An accurate DNA marker assay for stem rust resistance gene Sr2 in wheat. Theoretical and Applied Genetics 122: 735-744.Zhang N, Yang WX, Wang HY, wild relatives of wheat. Journal of Triticeae Crops 28: 691-696. wheat by a 'stepping -stone' procedure. Theoretical and Applied Genetics 87: 402-408.

Bariana HS, Brown GN, Bansal UK, Miah H, Standen GE, and Lu M. 2007. Breeding triple rust resistant wheat cultivars for Australia using conventional and marker-assisted selection technologies. Australian Journal of Agricultural Research 58: 576-587.

Jiang YY, Chen WQ, Zhao ZH, and Zeng J. 2007. Threat of new wheat stem rust race Ug99 to wheat production in China and counter measure. Plant Protection 27: 14-16.

Delibes A, Romero D, Aguaded S, Duce A, Mena M, Lopez-Brana I, Andrés MF, MartinSanchez JA, and García-Olmedo F. 1993. Resistance to the cereal cyst nematode (HeteroderaavenaeWoll.) transferred from the wild grass Aegilops ventricosa to hexaploid

Dyck PL, and Lukow OM. 1988. The genetic analysis of two inter specific sources of leaf rust 
337 resistance and their effect on the quality of common wheat. Canadian Journal of Plant $338 \quad$ Science 68: 633-639.

339

340

341

342

343

344

345

346

347

348

349

350

351

352

353

354

355

356

357

Peng X, Ren MJ, Zhang SS, and Xu RH. 2013. Molecular detection of wheat leaf rust resistance gene Lr34 and Lr37. Guizhou Agricultural Science 41: 13-16.

Xue WB, Xu X, Mu JM, Wang QL, Wu JH, Huang LL, and Kang ZS. 2014. Evaluation of stripe rust resistance and genes in Chinese elite wheat varieties. Journal of Triticeae Crops 34: 10541060.

Goutam U, Kukreja S, Tiwari R, Chaudhary A, Gupta RK, Dholakia BB, and Yadav R. 2013. Biotechnological approaches for grain quality improvement in wheat: present status and future possibilities. Australian Journal of Cereal Sciecce 7: 469-483.

Mago R, Verlin D, Zhang P, Bansal U, Bariana H, Jin Y, Ellis J, Hoxha S, and Dundas I. 2013. Development of wheat-Aegilops speltoides recombinants and simple PCR-based markers for Sr32 and a new stem rust resistance gene on the 2 s\#1 chromosome. Theoretical and Applied Genetics 126: 2943-2955.

Tsilo JT, Jin Y, Anderson JA. Microsatellite markers linked to stem rust resistance allele $\operatorname{Sr} 9 a$ in wheat. Crop Sci. 2007; 47: 2013-2020.

Helguera M, Khan IA, Kolmer J, Lijavetzky D, and Zhong-qi L. 2003. PCR assays for the Lr37Yr17-Sr38 cluster of rust resistance genes and their use to develop isogenic hard red spring wheat lines. Crop Science 43: 1839-1847.

Bansal U, Bariana H, Wong D, Randhawa M, Wicker T, Hayden M, and Keller B. 2014. Molecular mapping of an adult plant stem rust resistance gene Sr56 in winter wheat cultivar 
$358 \quad$ Arina. Theoretical and Applied Genetics 127: 1441-1448.

359 Periyannan S, Bansal U, Bariana H, Deal K, Luo MC, Dvorak J, and Laqudah E. 2014. 360 Identification of a robust molecular marker for the detection of the stem rust resistance gene 361 Sr45 in common wheat. Theoretical and Applied Genetics. 127: 947-955. 
Figure 1

Epidemic patterns of wheat stem rust in four wheat-producing regions in China.

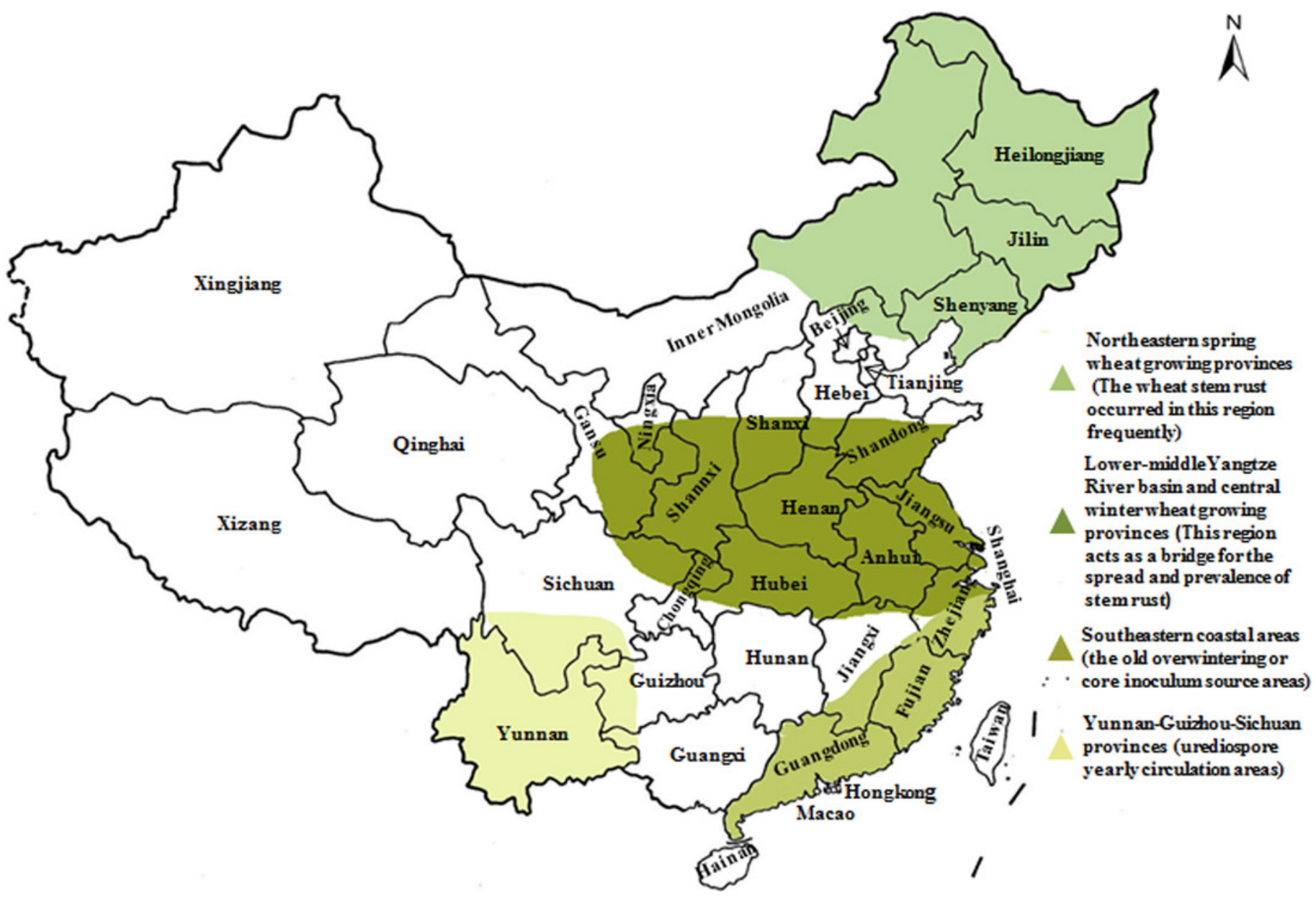


Figure 2

Screening for resistance genes against three Pgt races in wheat seedlings.

Seedling infection type (IT) scores have been converted to letters to facilitate reading: a, 0; b, -1; c, 1; d, 1+; e, 2; f, 3-; g, 3; h, 3+; I, 4 .

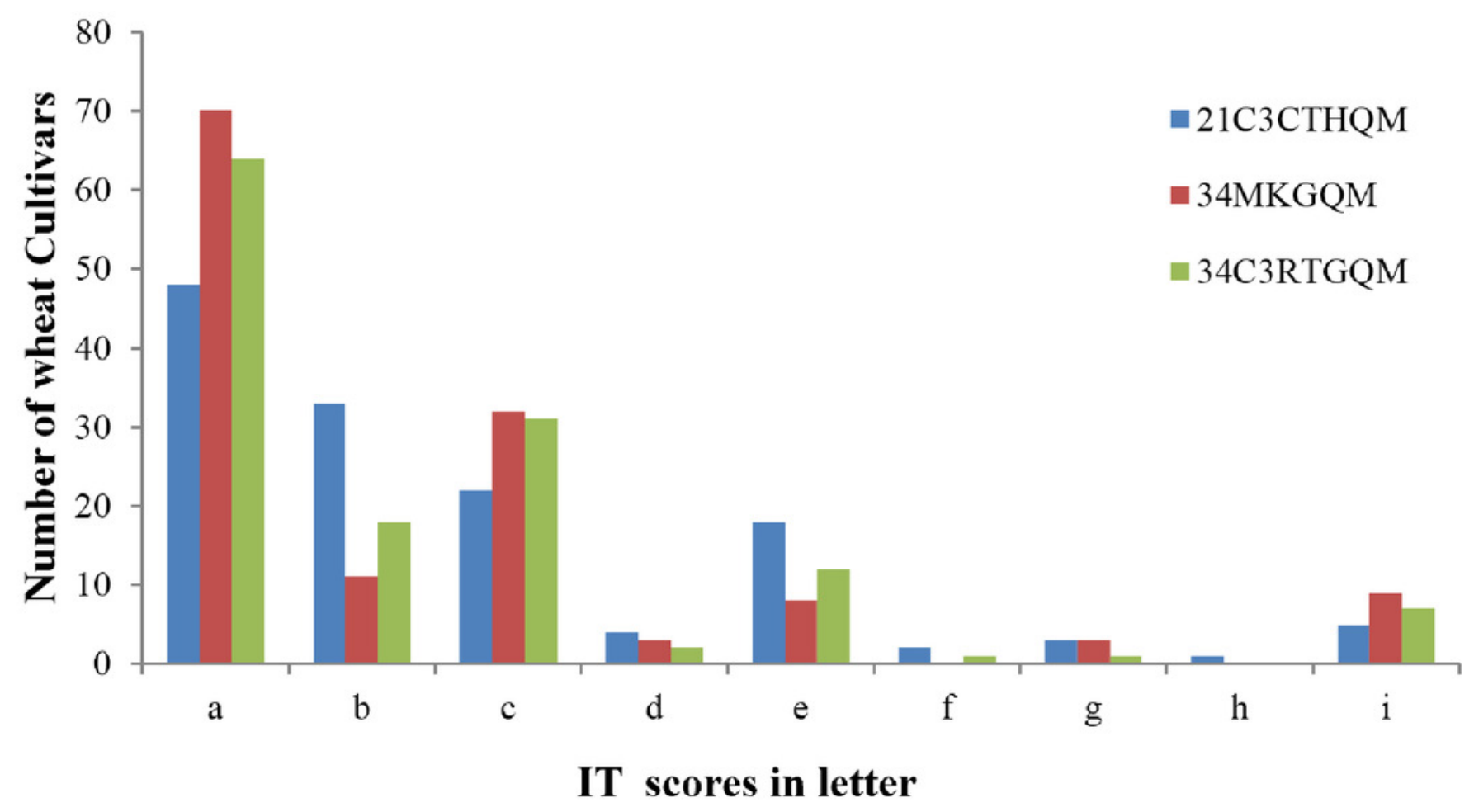


Figure 3

Amplification results for some of the wheat cultivars tested using six markers.

A, Xgwm533; B, Sr24\#12; C, Gb; D, Sr26\#43; E, SCSS30.2576; F, VENTRIUP-LN2. Lanes A1 to F1 are results of Hope, LcSr24Ag, Agatha/9*LMPG, Eagle, Sr31/6*LMPG, and Trident cultivars. Lanes 2 to 14 are Kenda 9, Kechun 8, Nongmai 850, Longfu 18, Kenjiu 9, Ningdong 11, Jimai 22, Yannong 19, Taishan 23, Ning 39, Ning 52, Wanmai 38, and Zhumai 762 cultivars. M is the DNA ladder used to identify the specific sequences of each molecular marker.

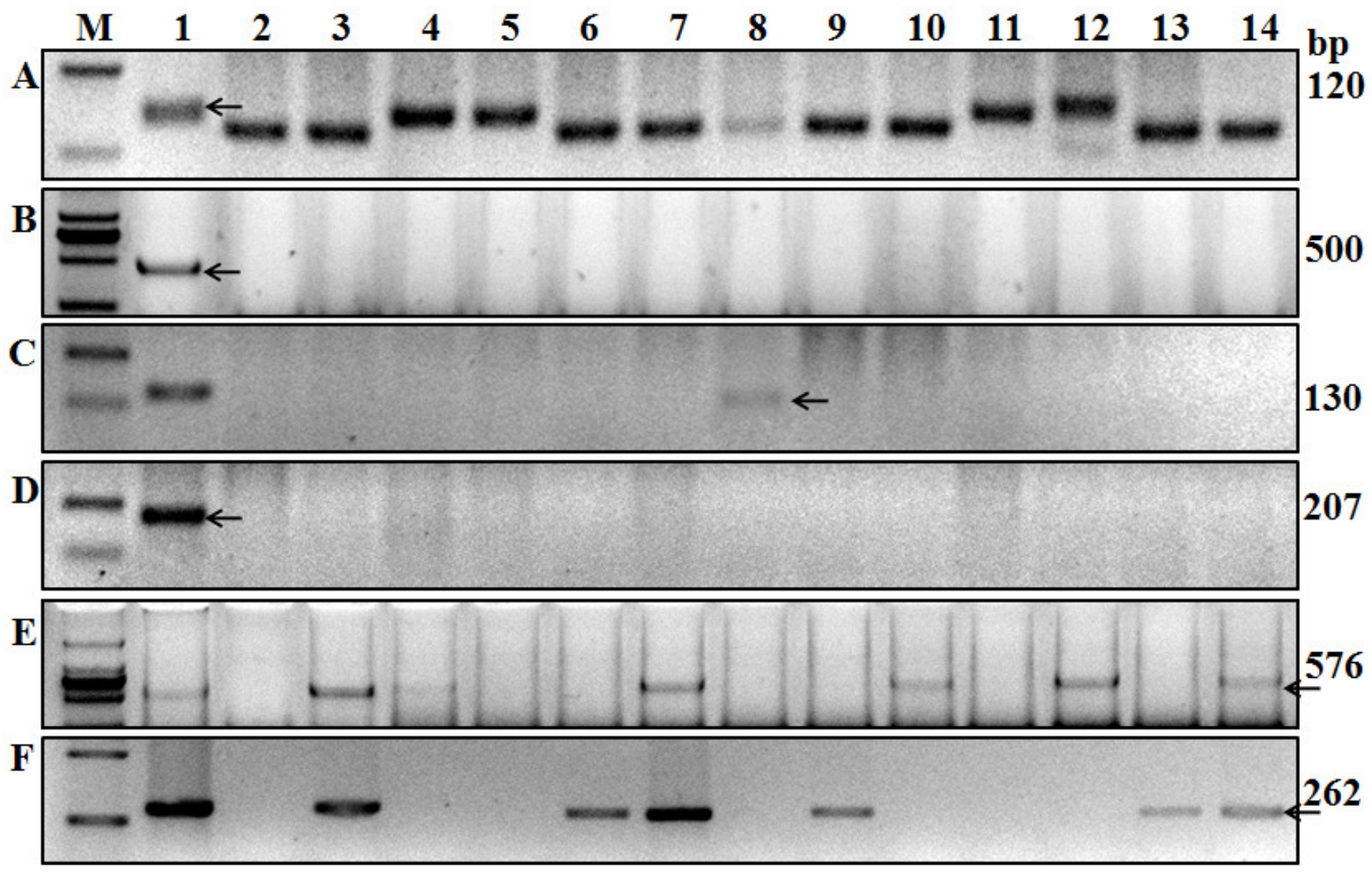




\section{Table 1 (on next page)}

PCR primers and conditions for the amplification of the tested markers 
2 Table 1. PCR primers and conditions for the amplification of the tested markers

\begin{tabular}{|c|c|c|c|}
\hline \multirow[t]{2}{*}{ Marker } & \multirow[t]{2}{*}{ Primers } & \multicolumn{2}{|l|}{ PCR conditions } \\
\hline & & Temperature $\left({ }^{\circ} \mathrm{C}\right) /$ time & Number of cycles cycle \\
\hline Xgwm533 & $\begin{array}{l}\text { 5'-GTTGCTTTAGGGGAAAAGCC } \\
\text { 5'-AAGGCGAATCAAACGGAATA }\end{array}$ & $\begin{array}{l}92 / 3 \mathrm{~min} ; \\
92 / 30 \mathrm{~s} ; 62 / 30 \mathrm{~s} ; 72 / 30 \mathrm{~s} \\
92 / 30 \mathrm{~s} ; 62 / 30 \mathrm{~s} ; 72 / 30 \mathrm{~s}\end{array}$ & $\begin{array}{l}\text { One } \\
1^{\circ} \mathrm{C} \text { Reducing/cycle for seven cycles } \\
\text { Forty- seven }\end{array}$ \\
\hline $\operatorname{Sr} 24 \# 12$ & $\begin{array}{l}\text { 5'-CACCCGTGACATGCTCGTA } \\
\text { 5'-AACAGGAAATGAGCAACGATGT }\end{array}$ & $\begin{array}{l}94 / 3 \mathrm{~min} \\
94 / 30 \mathrm{~s} ; 65 / 30 \mathrm{~s} ; 72 / 40 \mathrm{~s} \\
94 / 30 \mathrm{~s} ; 58 / 30 \mathrm{~s} ; 72 / 40 \mathrm{~s} \\
20 / 1 \mathrm{~min}\end{array}$ & $\begin{array}{l}\text { One } \\
1^{\circ} \mathrm{C} \text { Reducing/cycle for seven cycles } \\
\text { Thirty } \\
\text { One }\end{array}$ \\
\hline$G b$ & $\begin{array}{l}\text { 5'-CATCCTTGGGGACCTC } \\
\text { 5'-CCAGCTCGCATACATCCA }\end{array}$ & $\begin{array}{l}94 / 3 \mathrm{~min} \\
94 / 30 \mathrm{~s} ; 60 / 30 \mathrm{~s} ; 72 / 40 \mathrm{~s} \\
20 / 1 \mathrm{~min}\end{array}$ & $\begin{array}{l}\text { One } \\
\text { Thirty } \\
\text { One }\end{array}$ \\
\hline $\operatorname{Sr} 26 \# 43$ & $\begin{array}{l}\text { 5'-AATCGTCCACATTGGCTTCT } \\
\text { 5'-CGCAACAAAATCATGCACTA }\end{array}$ & $\begin{array}{l}94 / 3 \mathrm{~min} \\
94 / 30 \mathrm{~s} ; 56 / 30 \mathrm{~s} ; 72 / 40 \mathrm{~s} \\
20 / 1 \mathrm{~min}\end{array}$ & $\begin{array}{l}\text { One } \\
\text { Thirty } \\
\text { One }\end{array}$ \\
\hline $\operatorname{SCSS} 30.2_{576}$ & $\begin{array}{l}\text { 5'-GTCCGACAATACGAACGATT } \\
\text { 5'-CCGACAATACGAACGCCTTG }\end{array}$ & $\begin{array}{l}95 / 5 \mathrm{~min} ; 60 / 1 \mathrm{~min} ; 72 / 30 \mathrm{~s} \\
95 / 1 \mathrm{~min} ; 60 / 1 \mathrm{~min} ; 72 / 30 \mathrm{~s} \\
72 / 10 \mathrm{~min}\end{array}$ & $\begin{array}{l}\text { One } \\
\text { Thirty-five } \\
\text { One }\end{array}$ \\
\hline $\operatorname{Iag} 95$ & $\begin{array}{l}\text { 5'-CTCTGTGGATAGTTACTTGATCGA } \\
\text { 5'-CCTAGAACATGCATGGCTGTTACA }\end{array}$ & $\begin{array}{l}94 / 3 \mathrm{~min} \\
94 / 30 \mathrm{~s} ; 55 / 60 \mathrm{~s} ; 72 / 70 \mathrm{~s} \\
25 / 60 \mathrm{~s}\end{array}$ & $\begin{array}{l}\text { One } \\
\text { Thirty } \\
\text { One }\end{array}$ \\
\hline VENTRIUP-LN2 & $\begin{array}{l}\text { 5'-AGGGGCTACTGACCAAGGCT } \\
\text { 5'-TGCAGCTACAGCAGTATGTACACAAAA }\end{array}$ & $\begin{array}{l}94 / 45 \mathrm{~s} \\
94 / 45 \mathrm{~s} ; 65 / 30 \mathrm{~s} ; 72 / 7 \mathrm{~min} \\
72 / 1 \mathrm{~min}\end{array}$ & $\begin{array}{l}\text { One } \\
\text { Thirty } \\
\text { One }\end{array}$ \\
\hline
\end{tabular}

3 


\section{Table 2 (on next page)}

Seedling infection types and resistance genes

Seedling infection types produced by three races of $P$. graminis f. sp. tritici and Molecular detection of resistance genes Sr2 ,Sr24, Sr25, Sr26, Sr31, and Sr38 in the 136 wheat cultivars (lines). 
Table 2. Seedling infection types produced by three races of $P$. graminis f. sp. tritici and Molecular detection of resistance genes $S r 2, S r 24, S r 25, S r 26, S r 31$, and

$\operatorname{Sr} 38$ in the 136 wheat cultivars (lines)

\begin{tabular}{|c|c|c|c|c|c|c|c|c|c|c|c|c|}
\hline \multirow[b]{2}{*}{ Cultivars } & \multirow[b]{2}{*}{ Province } & \multirow[b]{2}{*}{ Pedigree } & \multicolumn{3}{|c|}{ Infection Types ${ }^{\mathrm{a}}$} & \multirow{2}{*}{$\begin{array}{c}\text { Sr2 } \\
X g w m \\
533 \\
\end{array}$} & \multirow{2}{*}{$\frac{S r 24}{\operatorname{Sr} 24 \# 12}$} & \multirow{2}{*}{$\frac{S r 25}{G b}$} & \multirow{2}{*}{$\begin{array}{c}\operatorname{Sr} 26 \\
\operatorname{Sr} 26 \# 43\end{array}$} & \multicolumn{2}{|c|}{$\operatorname{Sr} 31$} & \multirow{2}{*}{$\begin{array}{r}S r 38 \\
V E N T R I \\
U P-L N 2\end{array}$} \\
\hline & & & $\begin{array}{l}\text { 21C3 } \\
\text { CTHQM }\end{array}$ & $\begin{array}{l}34 \\
1 \text { MKGQM }\end{array}$ & $\begin{array}{l}34 \mathrm{C3} \\
\text { RTGQM }\end{array}$ & & & & & $\begin{array}{l}S C S S \\
30.2_{576}\end{array}$ & $\operatorname{Iag} 95$ & \\
\hline Xinkehan 9 & Heilongjiang & Kefeng $2 / \mathrm{Ke} 74 \mathrm{~F}_{3}-249-3$ & $; 1$ & 1 & $;$ & $-\mathrm{b}$ & - & - & - & - & - & - \\
\hline Kehan 2 & Heilongjiang & Jiusan 80 jian 119/Nongda75-65533 & $; 1$ & 1 & 1 & - & - & - & - & - & - & + \\
\hline Kehan 3 & Heilongjiang & $\mathrm{Ke}^{6} \mathrm{~F}_{3}-199$ /Agropyron glaucum & 0 & 0 & 0 & - & - & + & - & - & - & - \\
\hline Kehan 4 & Heilongjiang & Kezhen/Kehong & $; 1$ & 1 & $1+$ & - & - & - & - & - & - & + \\
\hline Kehan 8 & Heilongjiang & $\mathrm{Ke} 65 \mathrm{~F}_{2}-196-7 /$ Rulofen & ; & 0 & 0 & - & - & - & - & - & - & - \\
\hline Kehan 9 & Heilongjiang & Kefeng $2 / \operatorname{Ke} 74 \mathrm{~F}_{3}-249-3$ & ; & 0 & 0 & - & - & - & - & - & - & - \\
\hline Kehan 10 & Heilongjiang & Kefeng 2//T808/Ke 69-513 & ; & 1 & 0 & - & - & - & - & - & - & - \\
\hline Kehan 11 & Heilongjiang & Ke 73-402/Bei 74-205 & ; & 0 & 0 & + & - & - & - & - & - & - \\
\hline Kehan 12 & Heilongjiang & Ke $68-88 / \operatorname{Ke} 68-585-13$ & ; & 1 & 1 & - & - & - & - & - & - & + \\
\hline Kehan 13 & Heilongjiang & Kefeng 3/Kehan 8 & $; 1$ & 0 & 0 & - & - & - & - & - & - & - \\
\hline Kehan 14 & Heilongjiang & Ke $80-10-1 / \operatorname{Ke} 81$ hou $88-0-1$ & ; & $1-$ & 1 & - & - & - & - & - & - & + \\
\hline Kehan 15 & Heilongjiang & $\mathrm{Ke} 86 \mathrm{~F}_{2}-172 / \mathrm{Ke} 86 \mathrm{~F}_{5}-325-3$ & 0 & 0 & 0 & - & - & - & - & - & - & - \\
\hline Kehan 16 & Heilongjiang & $\begin{array}{l}\text { Jiusan } 79 \mathrm{~F} 5-541 / \mathrm{Ke} 80 \text { yuan } 229 / / \mathrm{Ke} 76- \\
750 / 76 \mathrm{~F} 4-779-5 / / \mathrm{Ke} 76-413\end{array}$ & 0 & 0 & 0 & - & - & - & - & - & - & + \\
\hline Kehan 18 & Heilongjiang & Jiusan 1989/Kefeng 5 & 0 & 0 & 0 & - & - & - & - & - & - & - \\
\hline Kehan 19 & Heilongjiang & Ke 90-99/ MY4490 & 1 & 0 & 0 & - & - & - & - & - & - & + \\
\hline Kehan 20 & Heilongjiang & Ke 89-46/ Cundo & $; 1$ & 0 & 0 & - & - & - & - & - & - & + \\
\hline Kehan 21 & Heilongjiang & $\mathrm{Ke} 89 \mathrm{~F}_{6}$ nan- $2 / \mathrm{Ke} 89 \mathrm{~F}_{1}-1237$ & 1 & 2 & 1 & - & - & - & - & - & - & - \\
\hline Kefeng 6 & Heilongjiang & Ke $85-869 / \operatorname{Ke} 85-784$ & $; 1$ & ; & 0 & - & - & - & - & - & - & - \\
\hline Kefeng 7 & Heilongjiang & $\mathrm{Ke} 84 \mathrm{~F}_{5}-250-1 / 84 \mathrm{~F}_{5}-668$ & ; & ; & 0 & - & - & - & - & - & - & - \\
\hline Kefeng 8 & Heilongjiang & Kehan $12 / \operatorname{Ke~} 82-371$ & 0 & 1 & ; & - & - & - & - & - & - & - \\
\hline Longfu 1 & Heilongjiang & Xinshuguang 3/Liaochun 8 & 0 & 1 & ; & - & - & - & - & - & - & - \\
\hline Longfu 2 & Heilongjiang & Longxi 35/Ke 250 & $; 1$ & 1 & ; & - & - & - & - & - & - & - \\
\hline Longfu 3 & Heilongjiang & Longfu 77-4096/S-A-25 & 0 & 0 & 0 & - & - & - & - & - & - & - \\
\hline Longfu 4 & Heilongjiang & Heiza 266/Ke 79F3-392 & ; & 1 & 1 & - & - & - & - & - & - & - \\
\hline Longfu 5 & Heilongjiang & Jiusan B29-/32P & 0 & 0 & 0 & - & - & - & - & - & - & - \\
\hline Longfu 6 & Heilongjiang & Longfu 2108/Haishu & 0 & 0 & 0 & - & - & - & - & - & - & - \\
\hline Longfu 7 & Heilongjiang & Longfu 3/Gang 98-446 & ; & 0 & 0 & - & - & - & - & - & - & - \\
\hline Longfu 8 & Heilongjiang & K202 60Co $1000 \mathrm{Rad}$ & 0 & 0 & 0 & - & - & - & - & - & - & - \\
\hline Longfu 9 & Heilongjiang & Kejian 23 60Co $180 \mathrm{~Gy}$ & 0 & 0 & 0 & - & - & - & - & - & - & - \\
\hline Lonfu 10 & Heilongjiang & Ke $87-183 \gamma 1.1 \mathrm{kRad}$ & 0 & 0 & 0 & - & - & - & - & - & - & - \\
\hline Longfu 11 & Heilongjiang & Longfu 81-8106 60 Co $\gamma 1.1 \mathrm{kRad}$ & 0 & 0 & 0 & - & - & - & - & - & - & + \\
\hline Longfu 12 & Heilongjiang & Jia 560 Co $\gamma$ & ; & ; & 0 & - & - & - & - & - & - & - \\
\hline Longfu 13 & Heilongjiang & Unkown & 2 & 1 & 1 & - & - & - & - & - & - & - \\
\hline Longfu 14 & Heilongjiang & $\mathrm{F}_{0}(\mathrm{Ke} 86 \mathrm{~F} 6-545 / \mathrm{Hei} 85-1584) \gamma 1.0 \mathrm{Rad}$ & 1 & 0 & 1 & - & - & - & - & - & - & - \\
\hline
\end{tabular}




\begin{tabular}{|c|c|c|c|c|c|c|c|c|c|c|c|c|}
\hline Longfu 16 & Heilongjiang & Unkown & 0 & 0 & $; 1$ & - & - & - & - & - & - & - \\
\hline Longfu 18 & Heilongjiang & Long 94-4083 mutagenesis & ; & 0 & ; & + & - & - & - & - & - & - \\
\hline Longfu 19 & Heilongjiang & SP4/Longmai 26 & o & 0 & 0 & - & - & - & - & - & - & - \\
\hline Longfu 20 & Heilongjiang & Xiaoyan 6/Long 94-4083 & $1-$ & 1 & 0 & - & - & - & - & - & - & - \\
\hline Longmai 10 & Heilongjiang & Dongnong 101/Yuanzhong 3908 & 0 & 0 & 0 & - & - & - & - & - & - & - \\
\hline Longmai 15 & Heilongjiang & Ke 76-686/Tieling 3 & 1 & $1+$ & ; & - & - & - & - & - & - & - \\
\hline Longmai 20 & Heilongjiang & Unkown & 0 & 0 & ; & - & - & - & - & - & - & - \\
\hline Longmai 23 & Heilongjiang & Unkown & 0 & 0 & 0 & - & - & - & - & - & - & - \\
\hline Longmai 24 & Heilongjiang & Unkown & 0 & 0 & 0 & - & - & - & - & - & - & - \\
\hline Longmai 26 & Heilongjiang & Long $87-7129 / \mathrm{Ke} 88 \mathrm{~F} 22060$ & $; 1$ & 0 & 0 & + & - & - & - & - & - & + \\
\hline Longmai 27 & Heilongjiang & Unkown & $; 1$ & 1 & 0 & - & - & - & - & + & + & - \\
\hline Longmai 30 & Heilongjiang & Long 90?05098/Long 90?06351 & 1 & 0 & 1 & - & - & - & - & - & - & + \\
\hline Longmai 31 & Heilongjiang & Longmai 20/PSN/BOW//Longmai 206 & 0 & 0 & 0 & - & - & - & - & - & - & - \\
\hline Longmai 32 & Heilongjiang & Long $94-4018 / \mathrm{Ke} 88 \mathrm{~F}_{2} 165-3$ & 0 & 0 & 0 & - & - & - & - & - & - & - \\
\hline Longmai 33 & Heilongjiang & Longmai 26/Jiusan 3u92 & ; & ; & 0 & + & - & - & - & - & - & - \\
\hline Longmai 34 & Heilongjiang & $\begin{array}{l}\mathrm{F}_{1} \text { (Zhong B054-3/2* Longmai } 15 / / 97 \\
\text { Chanjian489/3) /Longmai } 26\end{array}$ & ; & ; & ; & + & - & - & - & - & - & - \\
\hline Longmai 35 & Heilongjiang & Ke 90-513/Longmai 26 & $1-$ & 0 & 0 & - & - & - & - & - & - & + \\
\hline Longmai 36 & Heilongjiang & Ke $92-387 /$ Long $99 F_{3}-6725-1$ & 0 & 0 & $1-$ & - & - & - & - & - & - & - \\
\hline Longmai 37 & Heilongjiang & Long 2003M8059-3/Long 01D1572-2 & ; & 1 & 0 & + & - & - & - & - & - & - \\
\hline Longmai 39 & Heilongjiang & Long 03F3-6519/Longfu $20-378$ & 2 & 2 & 0 & + & - & - & - & - & - & - \\
\hline Kefeng 2 & Heilongjiang & Kehan $7 / \mathrm{Ke} 68 \mathrm{~F}_{4}-585-13$ & 0 & $1-$ & 1 & + & - & - & - & - & - & - \\
\hline Kefeng 3 & Heilongjiang & Kehan $8 /$ Kehong/Kezheng// Nadadoles & ; & $1-$ & ; & - & - & - & - & - & - & - \\
\hline Kefeng 4 & Heilongjiang & Ke 71F4-370-7/Moyi 66 & 0 & 0 & ; & - & - & - & - & - & - & - \\
\hline Kefeng 5 & Heilongjiang & $\mathrm{Ke} 76-250 / \mathrm{Ke} 76 \mathrm{~F} 4-799-5$ & 1 & 0 & 0 & - & - & - & - & - & - & - \\
\hline Kefeng 6 & Heilongjiang & Ke $85-869 / \operatorname{Ke} 85-784$ & $; 1$ & 2 & $1-$ & - & - & - & - & - & - & + \\
\hline Kefeng 10 & Heilongjiang & Kehan $12 / \mathrm{Ke} 89 \mathrm{RF}_{6} 287$ & 0 & 0 & ; & - & - & - & - & - & - & - \\
\hline Kenda 4 & Heilongjiang & $82-5621 / \mathrm{Ke} 79-369$ & 0 & 0 & 0 & - & - & - & - & - & - & - \\
\hline Kenda 5 & Heilongjiang & Longfu 5009/Nongda $84-838$ & 0 & 0 & 0 & - & - & - & - & - & - & - \\
\hline Kenda 6 & Heilongjiang & Nongda $89-2729 /$ Bei $89-22$ & 0 & $1-$ & 0 & - & - & - & - & - & - & - \\
\hline Kenda 7 & Heilongjiang & Nongda 89-2729/Bei 89-22 & 0 & 0 & 0 & - & - & - & - & - & - & - \\
\hline Kenda 8 & Heilongjiang & Nondda $89-2729 /$ Bei $86-1701$ & 0 & 0 & 0 & - & - & - & - & - & - & - \\
\hline Kenda 9 & Heilongjiang & Nongda $88-1116-8 /$ Bei88-26 & 2 & 1 & $1-$ & - & - & - & - & - & - & - \\
\hline Kenda 10 & Heilongjiang & Nongda 94-3537/Bei 90-1201 & 1 & 1 & 1 & - & - & - & - & - & - & - \\
\hline Kenda 11 & Heilongjiang & Jiusan $93 \mathrm{u} 92 / \mathrm{Ke} 90-514$ & 0 & 0 & 0 & - & - & - & - & - & - & - \\
\hline Kenda 12 & Heilongjiang & Jiadongmai 19/Nongda 96-2543 & 0 & 1 & $1-$ & - & - & - & - & - & - & - \\
\hline Kenda 13 & Heilongjiang & Unkown & 0 & 0 & 0 & + & - & - & - & - & - & - \\
\hline Kenjiu 9 & Heilongjiang & Xiyin 1/Jiusan 80-41123-7-3 & 0 & 0 & 0 & - & - & - & - & + & + & - \\
\hline Kenjiu 10 & Heilongjiang & Jiusan $84-7251 /$ Jiusan $87148 / / \mathrm{Ke}$ & 0 & 0 & $1-$ & - & - & - & - & - & - & + \\
\hline Kechun 2 & Heilongjiang & $\mathrm{Ke} 90-514 / \mathrm{Ke} 93 \mathrm{RF}_{6}-128 / / \mathrm{Ke} 90-514$ & ; & 1 & $1-$ & + & - & - & - & - & - & + \\
\hline Kechun 5 & Heilongjiang & Ke 99F2-33-3/Jiusan 94-9178 & 0 & 0 & 0 & - & - & - & - & + & + & \\
\hline Kechun 8 & Heilongjiang & Ke $99 F_{2}-33-3 /$ Jiusan $94-9178$ & 0 & 0 & 0 & - & - & - & - & + & + & + \\
\hline
\end{tabular}




\begin{tabular}{|c|c|c|c|c|c|c|c|c|c|c|c|c|}
\hline Kechun 9 & Heilongjiang & Ke $99 F_{2}-33-3 / J i u s a n ~ 94-9178$ & 0 & $1+$ & 2 & - & - & - & - & + & + & - \\
\hline Xiaobing 33 & Heilongjiang & A. glaucum/Triticum aestivum & 0 & 0 & 0 & - & - & - & - & - & - & - \\
\hline Beimai 6 & Heilongjiang & Jiusan 93-3U92/Ke 90-514 & 0 & 2 & 0 & - & - & - & - & - & - & + \\
\hline Beimai 9 & Heilongjiang & $\begin{array}{l}\text { Jiusan } 97 \mathrm{~F}_{4}-1057 / \text { Jiusan } 97 \mathrm{~F}_{4}-255 \mathrm{~F}_{1} / 119 \text { - } \\
\text { 54- 4- II -3 }\end{array}$ & 2 & 1 & 1 & - & - & - & - & - & - & + \\
\hline Longken 402 & Heilongjiang & Unkown & 1 & 1 & 0 & - & - & - & - & - & - & - \\
\hline 2010j159 & Heilongjiang & Unkown & 0 & 0 & 2 & + & - & - & - & + & + & - \\
\hline Norstar & Heilongjiang & Unkown & 1 & 2 & $1+$ & + & - & - & - & - & - & + \\
\hline Dongnong 125 & Heilongjiang & Unkown & $; 1$ & 0 & 2 & - & - & - & - & - & - & + \\
\hline Nongmai 850 & Beijing & Unkown & 1 & 0 & 0 & + & - & - & - & + & + & - \\
\hline Zhongmai 8 & Beijing & Hehua 971-3/Ji Z76 & $1+$ & 1 & 0 & - & - & - & - & - & - & + \\
\hline Jingdong 8 & Beijing & $\begin{array}{l}\text { Afuleer 5238-016/Hongliang } 4 / / \text { Jingnong } \\
79-106\end{array}$ & 2 & 0 & 1 & - & - & - & - & + & + & - \\
\hline Zhongmai 895 & Beijing & Zhoumai 16/Liken 4 & 1 & 0 & 1 & - & - & - & - & + & + & - \\
\hline Chimai 2 & Inner Mongolia & Wenge $7 /$ Kehan 6 & 1 & 0 & 1 & - & - & - & - & - & - & - \\
\hline Chimai 5 & Inner Mongolia & Wenge $1 / \mathrm{Ke} 76$ tiao 295 & $; 1$ & 1 & $1-$ & - & - & - & - & - & - & - \\
\hline Chimai 7 & Inner Mongolia & Ke 76 tiao 295/Wenge 1 & 2 & 1 & 1 & - & - & - & - & - & - & - \\
\hline Ba $13 p 51$ & Inner Mongolia & Unkown & ;1- & 0 & 1 & + & - & - & - & + & + & - \\
\hline Shannong 22 & Shandong & PH82-2-2/954072 & 2 & $1+$ & 2 & - & - & - & - & - & - & - \\
\hline Shannong 23 & Shandong & Tal $(\mathrm{Ms} 2)$ recurrent selection & 2 & 2 & 2 & - & - & - & - & + & + & - \\
\hline Shannong 24 & Shandong & Tal (Ms2) recurrent selection & $1-$ & 0 & 2 & - & - & - & - & + & + & - \\
\hline Jimai 19 & Shandong & Lunai 13/Linfen 5064 & 4 & 4 & 4 & - & - & - & - & - & - & - \\
\hline Jimai 20 & Shandong & Lunai 14/Lu 884187 & ; & 0 & 0 & + & - & - & - & - & - & + \\
\hline Jimai 21 & Shandong & 865186/Chuannongda 84-1109/Ji 84 -5418 & 3 & 4 & 4 & - & - & - & - & - & - & - \\
\hline Jimai 22 & Shandong & $935024 / 935106$ & 0 & 0 & 1 & - & - & + & - & - & - & + \\
\hline Jimai 44 & Shandong & Jinan $17 / 954027$ & 2 & ; & 2 & + & - & - & - & - & - & + \\
\hline Yannong 19 & Shandong & Yan 1933/Shan 82-29 & $; 1$ & ; & ; & - & - & - & - & - & - & + \\
\hline Yannong 21 & Shandong & Heyan 1933/Shan 8229 & $3-$ & 2 & 1 & - & - & - & - & - & - & - \\
\hline Yannong 23 & Shandong & Yan 1061/Lumai 14 & 3 & 4 & 3 & - & - & - & - & - & - & - \\
\hline Tainong 18 & Shandong & Laizhou 137/Yan 369-7 & 2 & 0 & 1 & - & - & - & - & - & - & - \\
\hline Taishan 23 & Shandong & $876161 / 881414$ & $1+$ & 0 & $1-$ & - & - & - & - & + & + & - \\
\hline Taishan 24 & Shandong & 904017/Zhenzhou 8329 & 3 & 4 & $3-$ & - & - & - & - & - & - & - \\
\hline Luyuan 502 & Shandong & 9940168/Jimai 19 & ; & 0 & 0 & - & - & - & - & + & + & - \\
\hline Tanmai 98 & Shandong & Jining $13 / 942$ & 4 & 3 & 2 & - & - & - & - & - & - & - \\
\hline Lumai 21 & Shandong & Yanzhong 144/Baofeng 7228 & $3+$ & 4 & 4 & - & - & - & - & - & - & - \\
\hline Jinan 17 & Shandong & Linfen 5064/Lumai 13 & 4 & 4 & 4 & - & - & - & - & - & - & - \\
\hline Liangxing 66 & Shandong & Ji91102/Ji 935031 & 2 & 3 & 1 & - & - & - & - & - & - & - \\
\hline Liangxing 99 & Shandong & Ji 91102/Lumai14//PH85-16 & $3-$ & 4 & 0 & - & - & - & - & - & - & - \\
\hline Zhoumai 28 & Henan & Zhoumai 18/Zhoumai 22//Zhou 2168 & 1 & ; & ; & - & - & - & - & + & + & - \\
\hline Zhumai 762 & Henan & Unkown & 2 & ; & ; & - & - & - & - & + & + & + \\
\hline Luomai 6010 & Henan & Yuanyang /Luo152/82C6/M & 2 & $; 1$ & 2 & - & - & - & - & - & - & - \\
\hline Guomai 301 & Henan & G883/Pumai 9 & 2 & 0 & 2 & - & - & - & - & - & - & + \\
\hline
\end{tabular}




\begin{tabular}{|c|c|c|c|c|c|c|c|c|c|c|c|c|}
\hline Zhoumai 27 & Henan & Zhoumai 16/Aikang 58 & 1 & 0 & ; & - & - & - & - & + & + & - \\
\hline Xumai 33 & Henan & Neixiang 991/Zhoumai 16 & 0 & 1 & 0 & - & - & - & - & + & + & - \\
\hline Xinmai 29 & Henan & Yanzhan 4110/Zhoumai 16 & 4 & 4 & 4 & - & - & - & - & - & - & - \\
\hline Annong 0711 & Henan & Yannong 19/Aanong 0016 & 2 & 1 & 2 & - & - & - & - & - & - & - \\
\hline Anke 157 & Henan & Taishan 241/Xinong 1718 & 2 & 3 & 4 & - & - & - & - & - & - & - \\
\hline Pumai 053 & Henan & Bainong AK58/Zhoumai 18 & 1 & 1 & 0 & - & - & - & - & + & + & - \\
\hline Kaimai 22 & Henan & Zhoumai 18/ Bainong AK58 & $1-$ & 1 & 0 & - & - & - & - & + & + & - \\
\hline Zhenmai 1860 & Henan & Unkown & 1 & ; & ; & - & - & - & - & + & + & - \\
\hline Womai 9 & Henan & Laizhou 953/Bainong AK58 & 1 & 1 & 1 & - & - & - & - & + & + & - \\
\hline Ning 52 & Ningxia & Yong 403/Yongliang 15//Yong 1147/230 & 0 & 0 & 0 & + & - & - & - & + & + & - \\
\hline Ning 39 & Ningxia & Yong 833/Ningchun 4 & ; & 0 & 0 & + & - & - & - & - & - & - \\
\hline Ningchun 4 & Ningxia & Suonuola 64/Hongtu & 0 & 0 & 0 & - & - & - & - & - & - & - \\
\hline Ning 51 & Ningxia & Yong 3002/Ningchun 4 & 0 & 0 & 0 & + & - & - & - & - & - & - \\
\hline Ningchun 53 & Ningxia & Ningchun 39/Moxige M7021 & 0 & 0 & 0 & + & - & - & - & - & - & - \\
\hline Ningdong 11 & Ningxia & RENAN//Beinong 2/Beijing 841 & $1+$ & 0 & 0 & - & - & - & - & + & + & + \\
\hline Linfeng 3 & Shanxi & Linyuan 86-7065/Linyuan 81-5011 & 2 & 0 & ; & - & - & - & - & - & - & - \\
\hline Jinmai 90 & Shanxi & Jinmai 47/02L013 & 4 & 4 & 4 & - & - & - & - & - & - & - \\
\hline Wanmai 38 & Jiangsu & Yanzhong 114/85-15-9 & $1+$ & 0 & 2 & - & - & - & - & - & - & + \\
\hline Wansu 0217 & Jiangsu & Unkown & 2 & 2 & 1 & - & - & - & - & - & - & - \\
\hline Huaimai 4064 & Jiangsu & Unkown & 1 & 1 & 1 & - & - & - & - & + & + & - \\
\hline Wanmai 1643 & Jiangsu & Unkown & 0 & 0 & 0 & + & - & - & - & - & - & - \\
\hline
\end{tabular}

${ }^{\text {a }}$ Infection types (ITs): are based on a 0-to-4 scale where ITs of 0, ;, 1, and 2 are indicative of a resistant (low) response and ITs of 3 or 4 of a susceptible (high) response; Symbols + and - indicate slightly larger and smaller pustule sizes, respectively (Stakman, Stewart \& Loegering, 1962).

${ }^{\mathrm{b}}$ Symbol '+' indicates the cultivar (line) carry the tested genes; '-' indicates the cultivar (line) don't carry the tested genes. 